ARTICLE

DOI: $10.1038 / s 41467-018-06030-6$

\title{
Water chemistry reveals a significant decline in coral calcification rates in the southern Red Sea
}

\author{
Zvi Steiner (1) ${ }^{1}$, Alexandra V. Turchyn (10 1, Eyal Harpaz² \& Jacob Silverman ${ }^{3}$
}

Experimental and field evidence support the assumption that global warming and ocean acidification is decreasing rates of calcification in the oceans. Local measurements of coral growth rates in reefs from various locations have suggested a decline of $\sim 6-10 \%$ per decade since the late 1990's. Here, by measuring open water strontium-to-alkalinity ratios along the Red Sea, we show that the net contribution of hermatypic corals to the $\mathrm{CaCO}_{3}$ budget of the southern and central Red Sea declined by $100 \%$ between 1998 and 2015 and remained low between 2015 and 2018. Measured differences in total alkalinity of the Red Sea surface water indicate a $26 \pm 16 \%$ decline in total $\mathrm{CaCO}_{3}$ deposition rates along the basin. These findings suggest that coral reefs of the southern Red Sea are under severe stress and demonstrate the strength of geochemical measurements as cost-effective indicators for calcification trends on regional scales.

\footnotetext{
${ }^{1}$ Department of Earth Sciences, University of Cambridge, CB2 3EQ Cambridge, UK. ${ }^{2}$ ZIM Integrated Shipping Ltd., Haifa, 31016, Israel. ${ }^{3}$ Israel Oceanographic \& Limnological Research, Haifa, 31080, Israel. Correspondence and requests for materials should be addressed to Z.S. (email: steinerz@gmail.com) or to J.S. (email: jacobs1@ocean.org.il)
} 
A bsorption of excess anthropogenic $\mathrm{CO}_{2}$ from the atmosphere into the oceans is reducing seawater $\mathrm{pH}$ and thus the carbonate ion concentration, making it increasingly more difficult for calcareous organisms to build their skeletons ${ }^{1,2}$. The anticipated decrease in $\mathrm{CaCO}_{3}$ production with increasing atmospheric $\mathrm{CO}_{2}$ and resulting ocean acidification will significantly impact many aspects of the marine carbon cycle and lead to the deterioration of shallow-water-carbonate platform habitats, such as coral reefs ${ }^{3,4}$. The effect of ocean acidification may be particularly hard for coral reefs as corals, which form the foundation of their carbonate framework will not be able to produce $\mathrm{CaCO}_{3}$ at a rate that will equal or offset the sum of mechanically and biologically mediated erosive processes 4 .

The adverse effects of ocean acidification on hermatypic coral calcification, as well as whole coral reef community calcification has been demonstrated experimentally in numerous laboratory experiments ${ }^{5}$ and two controlled field experiments ${ }^{6,7}$. These findings have motivated numerous studies of coral reef community metabolism, which established a baseline for our understanding of temporal variability in photosynthesis, respiration, calcification and $\mathrm{CaCO}_{3}$ dissolution rates of whole reef communities ${ }^{8-10}$. For example, measurements of community calcification made over two annual cycles in the Eilat Nature Reserve Reef, northern Red Sea, have been used to develop a gross coral reef calcification rate equation, which is a function of live coral coverage, reef-water temperature and aragonite saturation ${ }^{11}$. Using this equation, together with modelled values of sea surface temperature and aragonite saturation for different future levels of atmosphere $\mathrm{CO}_{2}$, it has been predicted that many tropical coral reefs might not be able to maintain their calcareous frameworks by the middle of the 21st century, when atmospheric $\mathrm{CO}_{2}$ is expected to double relative to its pre-industrial level ${ }^{4}$. Studies of community metabolism in the Great Barrier Reef compared rates of calcification measured in the past few years with similar measurements conducted 3-4 decades ago, which together suggested an alarming decline in net calcification rates, and confirmed the predicted decline according to the Eilat rate equation ${ }^{12,13}$. In addition, numerous coral growth records derived from coral cores taken from live corals in the Great Barrier Reef, Red Sea and reefs in southeast Asia indicated that growth rates have been continuously declining since the 1990's, on the order of $\sim 6-10 \%$ per decade ${ }^{14-16}$. In contrast, the same type of data suggests that coral calcification rates were stable in the decades preceding 1996 and 1998 in the Florida Keys and the Red Sea, respectively ${ }^{14,17}$.

The alarming global decline in the state of coral reefs is largely due to periods of prolonged thermal stress that are increasing in frequency and duration, resulting in massive coral bleaching and mortality ${ }^{18}$, in addition to local stress factors, such as coral mining and eutrophication ${ }^{19,20}$. This global decline in the state of coral reefs warrants careful monitoring of these important ecosystems. Assessment of the state of coral reefs has traditionally relied mostly on annual visual community structure surveys ${ }^{21}$. This method provides a wealth of information regarding the state of corals reef communities and allows the exploration of the processes that influence the state of the communities, yet the spatial coverage of these surveys is limited and they are very labour intensive. A different approach to assess the state of whole coral reef ecosystems is to measure changes in the water chemistry induced by biological activity, where precipitation of $\mathrm{CaCO}_{3}$ by reef organisms (mainly hermatypic corals) induces changes in seawater total alkalinity $\left(A_{T}\right)^{22,23}$. Furthermore, it has been proposed that this method can be applied to ocean basins or oceanic regions with a high prevalence of coral reefs, where changes in $\mathrm{A}_{\mathrm{T}}$, in conjunction with strontium and calcium concentrations that diverge from conservation with salinity can be used to determine the relative contributions of corals and calcareous plankton to their $\mathrm{CaCO}_{3}$ budget $^{24}$. In the oceans, $\mathrm{A}_{\mathrm{T}}$ is typically conservative with seawater salinity, which itself changes mostly due to evaporation and/or precipitation. Upward divergence from the oceanic conservation of $\mathrm{A}_{T}$ relative to salinity in surface waters indicates net dissolution of $\mathrm{CaCO}_{3}$ or independent production of $A_{T}$, while downward divergence of $A_{T}$ relative to salinity in surface waters indicates net $\mathrm{CaCO}_{3}$ precipitation or independent uptake of $A_{T}$. Thus, an increase in the slope of $A_{T}$ vs. salinity relative to a baseline slope in a defined oceanic region could indicate a decrease in net calcification. If the $A_{T}$ vs. salinity slope is higher than the slope of oceanic conservation, then it would indicate that the system has become a net source of $A_{T}$; being a source of alkalinity could indicate the dissolution of $\mathrm{CaCO}_{3}$ or an external supply of $\mathrm{A}_{\mathrm{T}}$, such as riverine or groundwater input ${ }^{25-27}$.

The physical oceanography of the Red Sea features several characteristics which make it an ideal basin for ocean-chemistrybased exploration and monitoring of the $\mathrm{CaCO}_{3}$ cycle. It is a long and narrow basin located in a hyper arid region with no significant river discharge or terrestrial runoff ${ }^{28}$. The only significant source of water to the Red Sea is surface water entering through the Straits of Bab-el-Mandeb, connecting the Red Sea with the Gulf of Aden and Indian Ocean ${ }^{29,30}$. The shallow sill at Bab-elMandeb prevents intermediate and deep Indian Ocean waters from entering the Red $\mathrm{Sea}^{29}$. Red Sea intermediate and deep waters form in the northern Red Sea and in the Gulfs of Aqaba and Suez, and are isolated from global ocean deep waters ${ }^{30,31}$. As a result, the Red Sea deep water mass has an unusually high temperature of $21^{\circ} \mathrm{C}$, maintaining supersaturation with respect to calcite and aragonite at all depths ${ }^{32}$. Upper thermocline water in the south and central Red Sea is warmer throughout the year and less salty than the deep and intermediate waters of the Red Sea, suppressing deep water formation and ventilation in these regions. The Red Sea is of particular interest in the context of ocean acidification and climate change since it is home to the world's longest continuous coral reef. The coral reefs of the southern Red Sea flourish under high summer time temperatures, which are generally above the thermal stress threshold considered to cause bleaching ${ }^{33}$.

A Rayleigh distillation model has been previously used to calculate the contribution of coral reefs and calcareous plankton to carbonate production along the Red Sea, Gulf of Aden and north-western Indian Ocean based on data collected in October-November $1998^{24}$. These calculations provide a baseline for long-term monitoring of changes in calcification on a basin scale, which we are now able to compare with new data collected along the Red Sea during December 2015-January 2016, April 2016 and March 2018 (Fig. 1). Comparing these new and old data, we find that changes in the salinity-normalized concentrations of strontium and $\mathrm{A}_{\mathrm{T}}$ along the north-south bisecting axis of the Red Sea indicate a $26 \pm 16 \%$ decline in net calcification rates between 1998 and 2015. This is a dramatic decrease for a region that has been previously declared a refuge for corals and coral reefs in an age of global warming and ocean acidification ${ }^{3,33}$. It seems that most of this decrease can be attributed to a reduction in net coral reef calcification rates in the tropical Red Sea while plankton calcification rates have also decreased. In addition, it is possible that dissolution in coral reefs increased as a result of coral bleaching, eutrophication and/or ocean acidification. Much of this region is presently inaccessible to researchers due to ongoing conflicts taking place in Yemen and Somalia, hence this large scale change could not be detected through standard visual surveys of coral reefs. This study demonstrates the strength of 


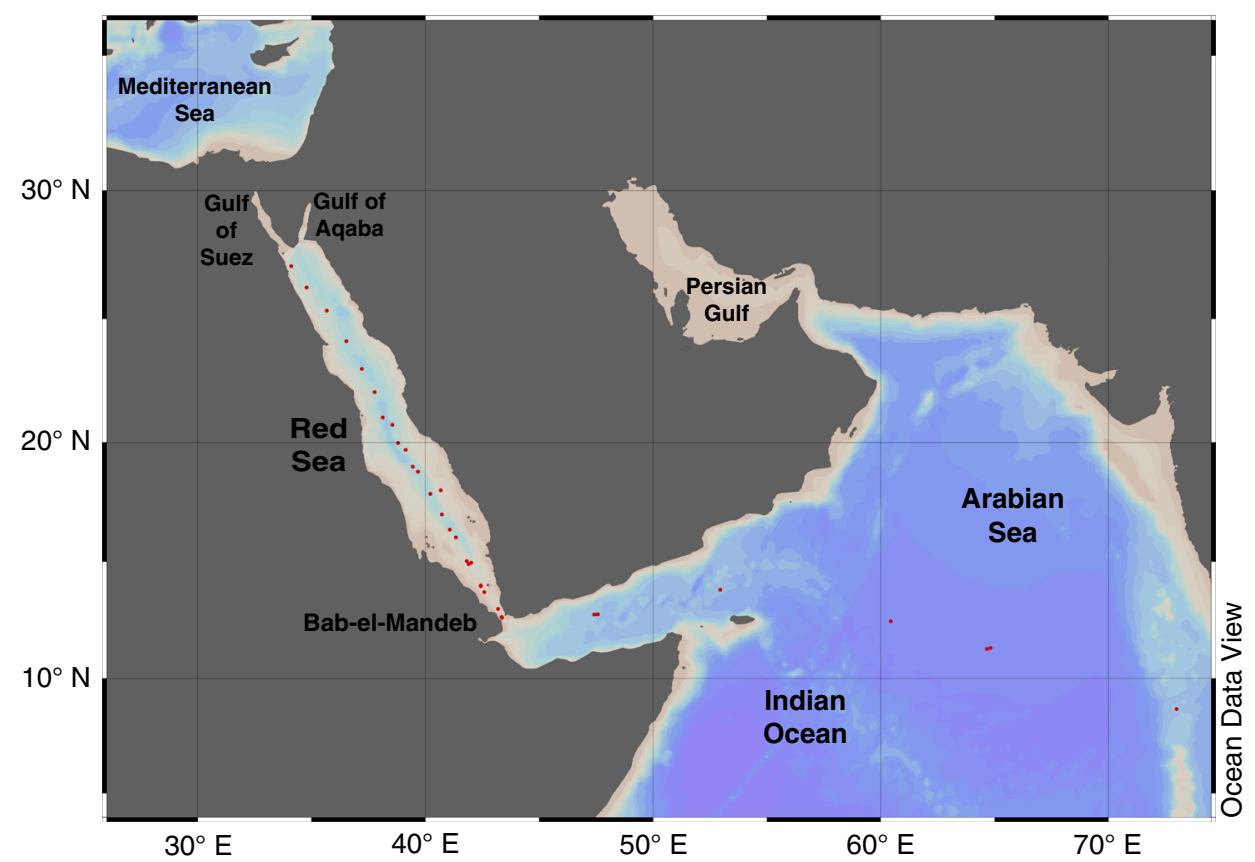

Fig. 1 Location map of surface water samples collected for the present study. The map was created using Ocean Data View 5.079. Supplementary Table 1 provides details of the exact sampling locations and times, and the physical and chemical parameters measured for the present work

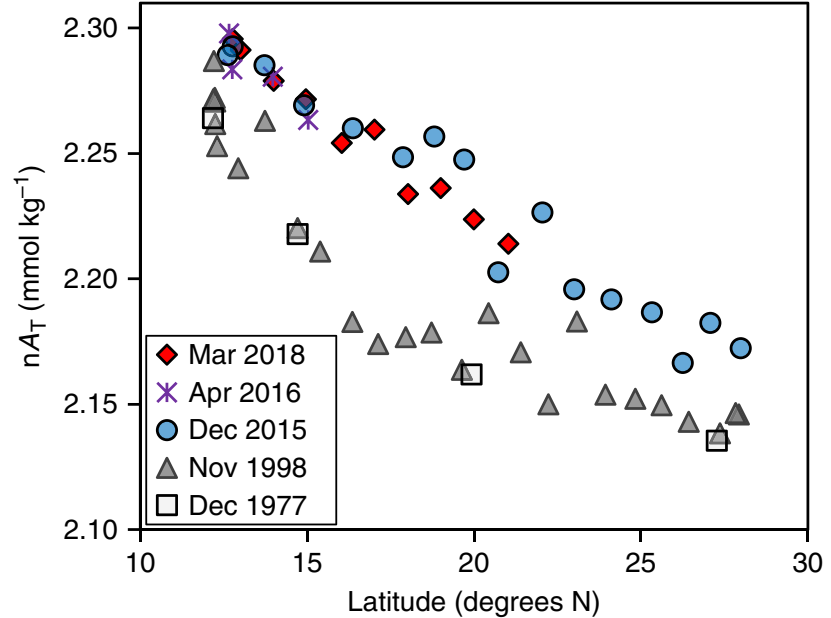

Fig. 2 Total alkalinity normalized to salinity of $35\left(n A_{T}\right)$ in the Red Sea and Gulf of Aden (West of $48^{\circ} \mathrm{E}$ ). Analytical uncertainties in the present and previous studies 24,35 are smaller than the symbol sizes

geochemical tools in establishing baselines and following trends to determine environmental status on a large spatial and temporal scale.

\section{Results and Discussion}

Changes in the $\mathrm{CaCO}_{3}$ budget of the Red Sea. The Red Sea region as a whole is a significant producer of $\mathrm{CaCO}_{3}$, and the bulk of this $\mathrm{CaCO}_{3}$ is not subsequently dissolved; as a result, the Red Sea region is a net sink for $\mathrm{CaCO}_{3}$. We can see this net sink of $\mathrm{CaCO}_{3}$ in the gradual decrease in salinity-normalized total alkalinity $\left(\mathrm{nA}_{T}\right)$ in the Red Sea surface water as it flows northward from the straits of Bab-el-Mandeb (Fig. 2). The $\mathrm{nA}_{\mathrm{T}}$ of the Red Sea deep water is lower than surface water $\mathrm{nA}_{\mathrm{T}}$ at the site of deep water formation, an observation that has been attributed to inorganic precipitation of $\mathrm{CaCO}_{3}$ on the surfaces of dust grains and re-suspended or deposited sediment grains ${ }^{34}$. Comparison of data collected during 2015-2018 with data collected in previous cruises along the Red Sea ${ }^{24,35}$ show that uptake of $A_{T}$ along the Red Sea transect decreased in 2015 relative to 1998 (Fig. 2). The $\mathrm{nA}_{\mathrm{T}}$ of surface water samples collected in April 2016 and March 2018 is similar to the December 2015 data. The spatial distribution of this uptake also changed, $\mathrm{A}_{\mathrm{T}}$ uptake decreased significantly in the southern Red Sea and western Gulf of Aden since 1998 and possibly increased from $20^{\circ} \mathrm{N}$ northward (Fig. 2), as the gap between the data sets becomes smaller in that region. The uptake of $A_{T}$ in the Red Sea is equivalent to the difference between the slope of $\mathrm{A}_{\mathrm{T}}$-to-salinity in the Red Sea and the Indian Ocean (IO) surface waters. In 1998, the slope of $A_{T}$-to-salinity between the IO and Red Sea was $26.6 \pm 2.0$, while in 2015 and 2018 the slope was $35.8 \pm 2.4$ (Fig. 3). Assuming that the residence time of water in the Red Sea did not change significantly between 1998 and 2015, the decrease in $\mathrm{A}_{\mathrm{T}}$ uptake in 2015 relative to 1998 is $26 \pm 16 \%$. The Indian Ocean $A_{T}$-to-salinity slope in 1998 and 2015-2018 remained unchanged with a value of $61.9 \pm 4.0$. The residence time of surface waters in the Red Sea is on the order of 1 year $^{36}$, hence each of the profiles presented in Figs. 2 and 3 represents a yearly cycle and should be sensitive to interannual variability.

The full data set suggests that the 2015 surface water data is reliable for calculations of calcification rates in the central and southern Red Sea but not in the northern Red Sea. Concentrations of calcium and $\mathrm{nA}_{\mathrm{T}}\left(\Delta \mathrm{Ca}^{+2}: \Delta \mathrm{nA} \mathrm{A}_{\mathrm{T}}\right)$ decrease at a ratio of $0.55 \pm 0.11$ mole mole $^{-1}$ along the southern and central Red Sea, in agreement with predicted ratios in precipitation of $\mathrm{CaCO}_{3}$. However, in the northern Red Sea (north of $24.1^{\circ} \mathrm{N}$ ), roughly one mole of calcium is added per two moles of $\mathrm{nA}_{\mathrm{T}}$ lost $\left(\Delta \mathrm{Ca}^{+2}\right.$ : $\Delta \mathrm{nA}_{\mathrm{T}}=-0.53 \pm 0.08$ mole mole $\left.{ }^{-1}\right)$. Such ratios are characteristic of hydrothermal activity and reactions between basaltic minerals and seawater ${ }^{37}$. Mineralogical transformations of fresh basalts and mixing of seawater with hydrothermal fluids replace calcium by magnesium, acting as a net source of dissolved calcium and sink of dissolved magnesium for the overlying seawater ${ }^{38-40}$. Strontium concentrations, on the other hand, are typically not significantly altered relative to chlorinity during high temperature circulation ${ }^{41}$. It was previously reported that surface water from 


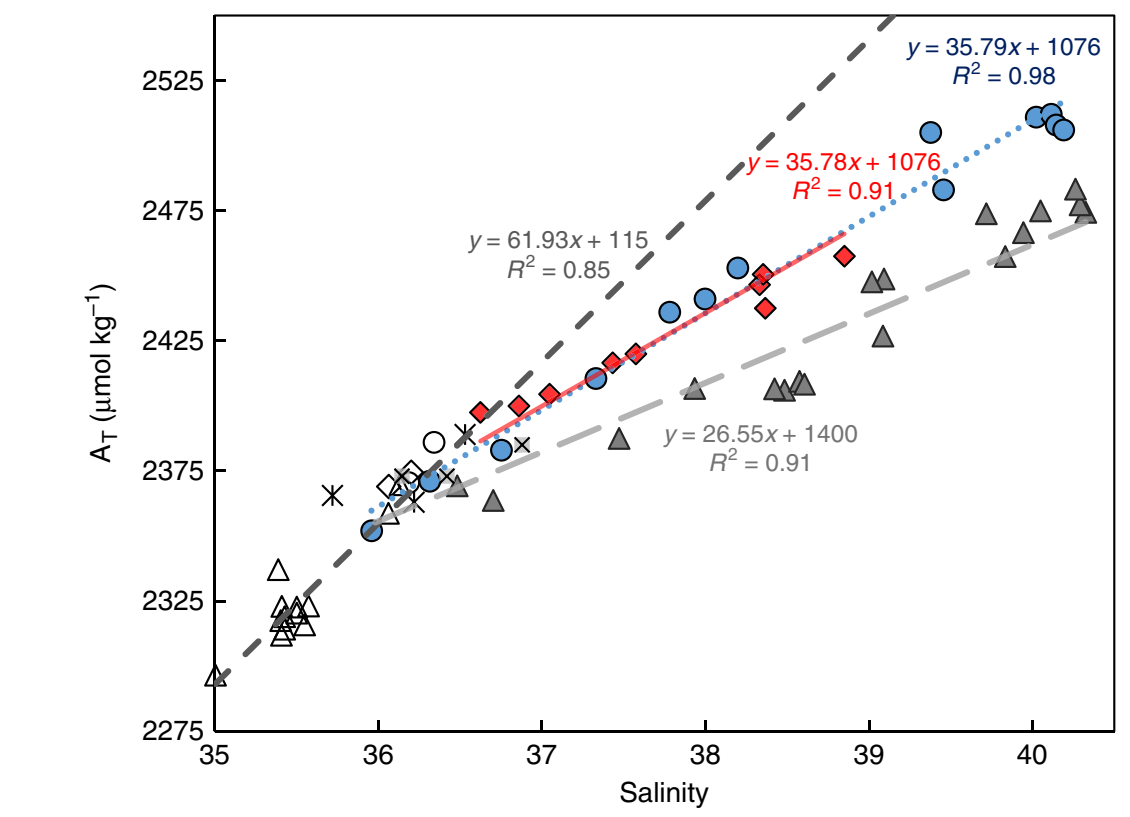

\begin{tabular}{|c|c|c|c|c|c|}
\hline$\Delta$ & IO-Nov1998 & O & IO-Dec2015 & $*$ & IO-Apr2016 \\
\hline$\diamond$ & IO-Mar2018 & $\Delta$ & RS-Nov1998 & 0 & RS-Dec2015 \\
\hline$x$ & RS-Apr2016 & $\diamond$ & RS-Mar2018 & -- & Linear (IO-Nov1998) \\
\hline - & - Linear (RS-Nov1998) & ...... & Linear (RS-Dec2015) & $\longrightarrow$ & - Linear (RS-Mar2018) \\
\hline
\end{tabular}

Fig. 3 Surface water total alkalinity versus salinity. The figure includes all surface water samples collected from the Indian Ocean (IO), Arabian Sea, Gulf of Aden and Red Sea (RS) in November 1998, December 2015, April 2016 and March 2018. Analytical uncertainties are smaller than symbol sizes

this region is slightly depleted in magnesium, an observation which further supports that hydrothermal/basalt alteration reactions are important ${ }^{24}$. The presence of hot brines in the deepest parts of the Red $\mathrm{Sea}^{40}$, as well as the overall relative narrowness of the basin, suggests that both sources are possible contributors of calcium. Unlike the northern Red Sea, mixing of brine waters into surface waters of the central and southern parts of the Red Sea is of minor importance due to the development of a steep density gradient between the surface and deep waters.

Relative contributions of corals and calcareous plankton. Each group of calcifying organisms precipitates $\mathrm{CaCO}_{3}$ with a typical tendency to incorporate strontium in the mineral lattice ${ }^{42}\left(K_{\mathrm{D}}\right.$, the distribution coefficient, is the ratio between a trace element and the major element in a solid versus the fluid it precipitates from). Corals precipitate aragonite with a slight preference for strontium over calcium $\left(K_{\mathrm{D}}^{\text {reef }}=1.04 \pm 0.03^{43}\right)$. The distribution coefficient of strontium in aragonite precipitated by red and green algae as well as inorganic aragonite are also high ${ }^{42,44}$. Common calcareous plankton, on the other hand, typically precipitate strontium-poor $\mathrm{CaCO}_{3}$. For example, planktonic foraminifera precipitate low Mg-calcite with typical strontium distribution coefficient of $K_{\mathrm{D}}=0.12$, while pteropods precipitate aragonite with $K_{\mathrm{D}}=0.12$, and coccolithophorids precipitate low Mg-calcite with a typical $K_{\mathrm{D}} \approx 0.3^{42,45,46}$. Taking all these calcifying plankton together, we can estimate an "average" distribution coefficient of strontium in planktonic $\mathrm{CaCO}_{3}$ precipitated in the Red Sea, $K_{D}^{\text {plankton }}$, is $0.17 \pm 0.03$, similar to the average value for biotic low magnesium calcite in general ${ }^{47}$. Because this number is significantly different from the distribution coefficient for strontium precipitated in corals $\left(K_{\mathrm{D}}^{\text {reef }}=1.04 \pm 0.03\right)$, by measuring the variations in strontium, calcium and alkalinity in the seawater along a transect we can determine the relative contributions of corals and calcareous plankton to the $\mathrm{CaCO}_{3}$ budget of a defined oceanic region.

The average distribution coefficient of strontium in all $\mathrm{CaCO}_{3}$ precipitated along a surface water flow trajectory can be calculated using the Rayleigh distillation equation ${ }^{24}$

$$
\frac{R_{\mathrm{w}}}{R_{0}}=f^{K_{\mathrm{D}}-1}
$$

where $R_{\mathrm{w}}$ is the $\mathrm{Sr} / \mathrm{Ca}$ or $\mathrm{Sr} / \mathrm{A}_{\mathrm{T}}$ ratio in each surface seawater sample; $R_{0}$ is the $\mathrm{Sr} / \mathrm{Ca}$ or $\mathrm{Sr} / \mathrm{A}_{\mathrm{T}}$ ratio in a reference sample and $f$ is the fraction of salinity normalized calcium or $\mathrm{A}_{\mathrm{T}}$ lost relative to the reference sample.

In the present work, we focus on changes in $\mathrm{A}_{\mathrm{T}}$ relative to salinity and $\mathrm{Sr} / \mathrm{A}_{\mathrm{T}}$ ratios since the relative changes in the concentrations of dissolved calcium were very small. If salinity normalized concentrations of calcium, $\mathrm{A}_{\mathrm{T}}$ and strontium change only due to precipitation of $\mathrm{CaCO}_{3}$, it is reasonable to assume a two-end-member system in which one end member is coral aragonite and the other is calcareous plankton, each with a typical distribution coefficient for strontium in its precipitated carbonate (much lower for calcareous plankton than for coral aragonite). Under this assumption, the relative net contributions of plankton

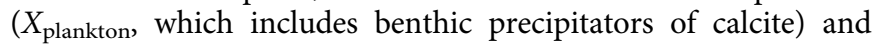
corals $\left(1-X_{\text {plankton, which includes inorganic aragonite) to the }}\right.$ $\mathrm{CaCO}_{3}$ budget in the Red Sea can be expressed by Eq. (1) and solved using a water mass chemical balance ${ }^{24}$.

$$
K_{\mathrm{D}}=K_{\mathrm{D}}^{\text {plankton }} \cdot X_{\text {plankton }}+K_{\mathrm{D}}^{\mathrm{reef}} \cdot\left(1-X_{\text {plankton }}\right)
$$

An important underlying assumption of the Rayleigh distillation model is that there is no back reaction ${ }^{48}$, i.e. no dissolution of $\mathrm{CaCO}_{3}$. Thus, Eq. (1) is not typically suitable for assessments of the $\mathrm{CaCO}_{3}$ cycle in deeper water masses or in shallow water 
environments where inorganic or biogenic dissolution, respectively may play an important role in their $\mathrm{CaCO}_{3}$ budget. In the Red Sea, deep water $\mathrm{CaCO}_{3}$ dissolution is not prevalent because of the high temperature and saturation states of $\mathrm{CaCO}_{3}$ minerals. In-situ dissolution of $\mathrm{CaCO}_{3}$ at the site of its formation, as part of the diurnal cycle, does not measurably modify the chemistry of the water far away from the reef as long as dissolution is balanced by accretion, hence this natural process is normally transparent in our calculations. An additional underlying assumption of the model is that all calcification processes occurring within a body of water are reflected by its chemical composition, i.e. laterally mixed. The Red Sea has a channel like structure and a single significant entry point, ensuring that nearly all water found in the surface layer of the northern Red Sea originated from the strait of Bab-el-Mandeb, connecting the Red Sea with the Gulf of Aden and the Indian Ocean. Within this channel, a series of mesoscale eddies vigorously mixes the upper water column on the longitudinal axis ${ }^{30}$, as reflected by the zonation of many physical and biological parameters ${ }^{49}$.

The average distribution coefficient of strontium in the precipitated $\mathrm{CaCO}_{3}$, as calculated using the Rayleigh distillation model for the south and central Red Sea, declined from $0.36 \pm$ 0.20 in 1998 to $0.11 \pm 0.06$ in 2015 and $0.11 \pm 0.07$ in March 2018 (Fig. 4). The earlier value has large margins of uncertainty when calculated based on $\mathrm{Sr} / \mathrm{A}_{\mathrm{T}}$ ratios alone, yet it is in excellent agreement with calculations based on calcium concentrations as well as long term records of coral and plankton calcification rates in this region, supporting its accuracy ${ }^{24}$. In terms of relative contributions, the 2015 and 2018 average distribution coefficients for the Red Sea suggest that the current regional $\mathrm{CaCO}_{3}$ cycle is dominated by planktonic foraminifera and pteropods, while the earlier average $K_{\mathrm{D}}$ suggests that $\sim 20 \%$ of the $\mathrm{CaCO}_{3}$ was precipitated in coral reefs along with possible contributions from coccolithophores ${ }^{24}$. These water-chemistry based calculations are

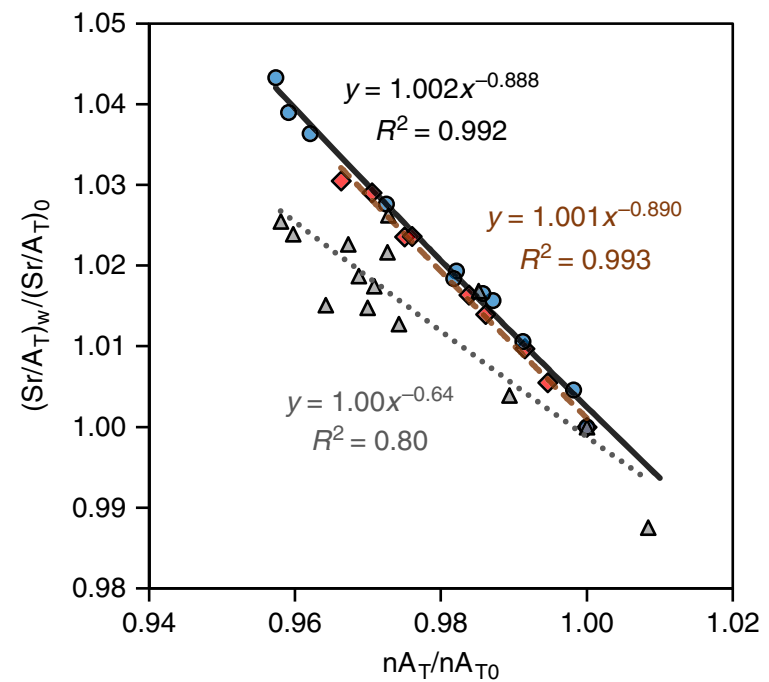

\begin{tabular}{|c|c|c|}
\hline$\diamond$ & Mar 2018 & o $\quad$ Dec 2015 \\
\hline$\Delta$ & Nov 1998 & $\ldots \mathrm{KD}=0.11(\operatorname{Mar} 2018)$ \\
\hline & $\mathrm{KD}=0.11(\mathrm{Dec} 2015)$ & ….... KD $=0.36($ Nov 1998) \\
\hline
\end{tabular}

Fig. 4 Calculation of the average distribution coefficient of strontium in $\mathrm{CaCO}_{3}$ precipitated along the southern and central Red Sea (Bab-elMandeb to $24^{\circ} 07^{\prime} \mathrm{N}$ ). Data collected in 1998 is from ref. ${ }^{24}$. Power of the trendline equals the distribution coefficient minus one (Eq. (1)). The average distribution coefficient of strontium in $\mathrm{CaCO}_{3}$ was therefore $0.36 \pm$ 0.16 in 1998, $0.11 \pm 0.06$ in 2015 and $0.11 \pm 0.07$ in 2018 with 95\% confidence intervals supported by reports of severe coral bleaching along the central Red Sea coast of Saudi Arabia in $2015^{18,50}$ and suggest that the extent of this bleaching event included the southern Red Sea. Our calculations also suggest that calcification rates of the southern and central Red Sea corals remain low and that the decrease represents a prolonged episode rather than a short term event isolated in 2015. By subtraction, the decrease in total calcification rates and coral calcification rates of the southern and central Red Sea suggests that calcification rates of foraminifera and pteropods decreased by $7.5 \pm 7.5 \%$. It should be noted that in any case this decrease in $K_{\mathrm{D}}$ does not mean that all corals are dead in this region but rather indicates an overall equilibrium between $\mathrm{CaCO}_{3}$ production and dissolution in coral reefs and shallow carbonate sediments derived from coral reef erosion. Any further decline in reef calcification rates or increase in dissolution rates should result in net loss of $\mathrm{CaCO}_{3}$ from the reef framework and ultimately the degradation and loss of this important habitat.

A difficulty that has to be taken into account when considering the validity of the Rayleigh distillation model in assessments of contributions to the $\mathrm{CaCO}_{3}$ cycle is that strontium can be removed/supplied by additional sources. Hydrothermal activity does not seem to be significant in this respect since reactions between seawater and basaltic minerals act in opposite direction to mixing hydrothermal fluids with seawater, cancelling the effects of each other ${ }^{41}$. There are also no significant rivers flowing into the Red Sea. Acantharia, which are radiolarian precipitating $\mathrm{SrSO}_{4}$ skeletons may be abundant in the surface mixed layer throughout the region ${ }^{51}$. Precipitation of $\mathrm{SrSO}_{4}$ is expected to remove large amounts of strontium from the water, increasing the apparent distribution coefficient of strontium, while dissolution of even small amounts of acantharia may decrease the apparent distribution coefficient to below zero. Given that seawater is highly undersaturated with respect to $\mathrm{SrSO}_{4}{ }^{52}$, its imprint on profiles of strontium concentrations depends on the export efficiency of the shells of these plankton. It was previously shown that dissolution rates of silicate radiolarians in the undersaturated water column increase exponentially with increasing temperatures $^{53}$ and it is likely that the same is true for the far more soluble acantharia shells. Absence of apparent contribution by precipitation/dissolution of acantharia shells to the $\mathrm{Sr} / \mathrm{Ca}$ ratios of the Red Sea in the southern and central Red Sea data, suggest that the vast majority of the acantharia dissolve within the warm surface mixed layer of this region. For the 1998 data set it was shown that there is excellent agreement between calculated precipitation rates of corals and calcareous plankton with satellite and sediment core data from this region, suggesting that the relative contribution of acantharia was not significant for our budget calculations ${ }^{24}$.

Long term trends in the Gulf of Aqaba. The northernmost Gulf of Aqaba is the only region in the Red Sea system in which longterm monitoring of the ecology and chemistry of the marine environment has been conducted routinely since the 1990's. Located at the terminus of the Red Sea surface water flow, water chemistry in the Gulf of Aqaba sums the processes occurring along the Red Sea with a likely overrepresentation of local processes occurring within the Gulf. In the northern Gulf of Aqaba, coral cover and the density of colonies declined significantly during the 1990's and reached an alarming low in $2004^{54}$. This decline was considered to be a result of eutrophication due to nutrient emissions from nearby fish farm activity $8,54,55$. The state of the coral reef in Eilat improved after 2004, following reductions in fish production and ultimate removal of this nutrient source between 2006 and 2008 56,57 . Changes in the abundance and species composition of planktonic foraminifera in recent decades 
have also been reported in the Gulf of Aqaba ${ }^{58}$. Monthly measurements of $A_{T}$ in the northern Gulf of Aqaba suggest a decline in calcification rates between 1999 and $2004^{59}$ and relative longterm stability with seasonal and inter-annual variability since $2008^{34,56}$. Recorded increase in $\mathrm{A}_{\mathrm{T}}$ of the surface waters of the Gulf of Aqaba in the years following 1998, probably reflects the local decline in the state of coral reefs in the northern Gulf of $\mathrm{Aqaba}^{54}$ as well as decreased calcification rates along the main basin of the Red Sea ${ }^{14,60}$.

Factors contributing to reduced calcification rates. Three main processes are most likely to contribute to reduced calcification rates along the southern Red Sea: Decreased carbonate ion concentration and aragonite saturation due to absorption of anthropogenic $\mathrm{CO}_{2}$ by the surface waters ${ }^{61}$. Increased temperatures in this already very warm region $14,50,62,63$. Eutrophication, which may support colonization of hard substrates by macro algae and displacement of reef building corals, as well as the increase in boring activity (biogenic dissolution of $\mathrm{CaCO}_{3}$ ) by organisms that inhabit the $\mathrm{CaCO}_{3}$ framework of coral reefs ${ }^{19,64}$ and the bacterially mediated dissolution of carbonate sediments, which is also affected by ocean acidification ${ }^{20,65,66}$. In the following discussion, we shall see that all three processes probably contribute to the observed decline.

Rates of coral calcification strongly depend on the saturation state of aragonite ${ }^{11}$. The same is probably also true for calcite precipitation by foraminifera ${ }^{67}$. The partial pressure of $\mathrm{CO}_{2}$ in surface waters of the Red Sea have been shown to be near equilibrium with atmospheric $\mathrm{CO}_{2}{ }^{68}$, hence the ecosystem should quickly respond to changes in atmospheric $\mathrm{CO}_{2}$. At the temperature-salinity range in the study area, increased temperatures increase the aragonite saturation state by 0.03 units-perdegree Celsius and may either increase or decrease biotic calcification rates, depending on the physiological response of organisms to temperatures. A null hypothesis of no change in live coral cover suggests that the increase in $\mathrm{pCO}_{2}$ and warming of $0.25^{\circ} \mathrm{C}^{63}$ between 1998 and 2015 should have decreased net coral calcification rates along the Red Sea by $4.4 \%$, based on the observed response of a coral reef community in the Gulf of Aqaba to seasonal changes in the saturation state of aragonite and temperature (ref. 11; Supplementary Fig. 1). Therefore, the dramatic decline in net coral calcification rates in the southern and central Red Sea as inferred from Figs. 2 to 4 must result from additional processes.

Reduced rates of coral calcification and reduced abundance of large corals since 1998 has been previously reported for several Red Sea reefs ${ }^{14,60}$. It was suggested that this decline in coral growth rates was a result of a long series of warm years in the central Red Sea ${ }^{14}$. In 2015, global temperatures were particularly high and widespread coral bleaching events were reported globally, including sites in the central Red Sea, Persian Gulf and Indian Ocean ${ }^{18,50,62}$. In the Red Sea, sea surface temperatures in 2015 were $0.5^{\circ} \mathrm{C}$ higher than the long term average, yet while 2015 was warmer than average for this region, it was not the warmest on record in recent years ${ }^{63}$. The bleaching event clearly affected the metabolic state of Red Sea corals yet coral bleaching is a very rapid process, which is unlikely to induce a gradual decline in coral growth as documented for the central Red Sea ${ }^{14}$. It therefore seems that while bleaching played a major role in decreasing coral calcification rates, change in calcification rates started earlier. Data from April 2016 and March 2018 show that recovery from the 2015 bleaching event has yet to happen.

A third possible contributor to the observed decline in southern Red Sea net calcification rates is increased erosion. Increased nutrient availability and subsequent growth of epilithic algae, increases the activity of boring organism and dissolution rates of $\mathrm{CaCO}_{3}$ in coral reefs ${ }^{69,70}$ as well as bacterially mediated dissolution of carbonate sediments and rubble ${ }^{20}$. For example, between 1960-1970 and 2009, the night-time dissolution rate of a reef in One Tree Island increased from 31 to $71 \%$ of the gross calcification rates, a three-fold increase in absolute terms ${ }^{13}$, likely driven by warming and ocean acidification.

Much like the Gulf of Aqaba, the central and southern parts of the Red Sea are increasingly threatened by overfishing, urban development and eutrophication ${ }^{71}$. The effect of eutrophication on trophic levels in central Red Sea coral reefs has been clearly documented $^{72}$ and should impact the whole community growth and calcification rates. Support for this claim comes from the average regional distribution coefficient of strontium, suggesting that coccolithophores calcification rates have also decreased. Calcification rates by coccolithophores are less likely to respond dramatically to small changes in temperature or $\mathrm{pCO}_{2}$ and more likely to be affected by eutrophication and pollution as these give rise to increased abundance of faster growing species ${ }^{73,74}$.

\section{Methods}

Sampling. During 27/12/2015-3/1/2016, 18-21/4/2016 and 23-31/03/2018 seawater samples were collected from the sea surface by bucket off the deck of the Container Ships ZIM Qingdao and Yokahama during their passage northward from the Arabian Sea through the Gulf of Aden and the Red Sea on their way to the Mediterranean (Fig. 1). Water samples were kept in refrigeration in $1.5 \mathrm{~L}$ gas tight plastic bottles until they were subsampled at the Israel Oceanographic and Limnological Research (IOLR) lab in Haifa, Israel within 3 days from collection of the last sample. Water samples for total alkalinity $\left(\mathrm{A}_{\mathrm{T}}\right)$, dissolved inorganic carbon (DIC) and density were kept in brown glass bottles and samples for $\mathrm{Sr}, \mathrm{Ca}$ and $\mathrm{Na}$ analysis were kept in polypropylene tubes. Samples for $\mathrm{A}_{\mathrm{T}}$, DIC and density were measured within the first week after arriving at IOLR.

Carbonate chemistry. Total alkalinity was determined at IOLR by potentiometric Gran titration of $\sim 22 \mathrm{~g}$ subsamples, filtered through Whatman GFF $0.45 \mu \mathrm{m}$ filters using a Metrohm Titrino 785 Titrameter with a temperature corrected $\mathrm{pH}$ probe and $\mathrm{HCl} 0.05 \mathrm{~N}$. $\mathrm{A}_{\mathrm{T}}$ was calculated from the intercepts and slopes of the linear regression fits between measured $\mathrm{pHs}$ and corresponding acid volumes in the $\mathrm{pH}$ range 3.8 and $3.3^{75}$. The acid concentration was calibrated using seawater CRMs from A. Dickson's lab. The precision of these measurements was $\pm 2 \mu \mathrm{mol} \mathrm{kg}^{-1}$ (two measurements per sample). The DIC was extracted from $1.6 \mathrm{~mL}$ sub-samples by acidifying them with phosphoric acid $\left(\mathrm{H}_{3} \mathrm{PO}_{4}, 10 \%\right)$ using an automated $\mathrm{CO}_{2}$ extractor and delivery system (AERICA by MARIANDA) and high grade $\mathrm{N}_{2}$

(99.999\%) as a carrier gas connected on line with a LiCor $6252 \mathrm{IR} \mathrm{CO}_{2}$ analyser. Measurements were calibrated using seawater Dickson CRMs. The repeatability of the measurements was $1.7 \pm 1.3 \mu \mathrm{mol} \mathrm{kg}{ }^{-1}$ (mean \pm STD of all measurement errors, $n=28)$.

Salinity. Salinity was calculated from density measurements conducted at IOLR using an Anton-Paar density and sound velocity metre, model DSA $5000 \mathrm{M}$. Together with the recorded temperature at the time of the measurements the results were input into the international equation of state for seawater ${ }^{76,77}$. The roots of the resulting polynomial with salinity as the unknown variable were calculated using the Newton-Raphson method. Validation of this method was done with a Dickson CRM and IAPSO standard seawater producing an accuracy of better than \pm 0.003 .

Major elements. Concentrations of calcium, strontium and sodium were measured at the University of Cambridge by inductively coupled plasma optical emission spectroscopy using an Agilent Technologies 5100 ICP-OES. Samples were diluted with $0.1 \mathrm{~N} \mathrm{HNO}_{3}$ at 1:71 ratio and analysed in duplicates by sample standard bracketing. Initial calibration lines were obtained by running different dilutions of IAPSO seawater batch P157. For accuracy calibrations, IAPSO seawater was spiked with a ${ }^{42} \mathrm{Ca}-{ }^{48} \mathrm{Ca}$ spike; calcium was separated by ion chromatography by running the samples through $\mathrm{Sr}$ spec resin followed by AG50W-X8 resin and measured by Thermo Scientific Triton Plus thermal ionization mass spectrometry (TIMS). Sr/Ca ratios and the concentrations of strontium were verified by running a standard with a known Sr/Ca ratio, prepared by Mervyn Greaves and utilized in many previous studies at the laboratory of Harry Elderfield. For this study, we used the Ca422.673, Sr421.552 and Na468.821 spectral lines. $1 \sigma$ standard deviation of the analyses was $0.12 \%$ and $0.11 \%$ for $\mathrm{Ca} / \mathrm{Na}$ and $\mathrm{Sr} / \mathrm{Na}$ ratios, respectively $(n=33)$. All calcium and strontium measurements were normalized to salinity of 35 by assuming sodium concentrations of $468.5 \mathrm{mmol} \mathrm{kg}^{-1}$ at that salinity ${ }^{78}$ 


\section{Data availability}

All data supporting the findings of this study is provided in the online Supplementary Information.

Received: 19 January 2018 Accepted: 3 August 2018

Published online: 06 September 2018

\section{References}

1. Feely, R. A. et al. Impact of anthropogenic $\mathrm{CO}_{2}$ on the $\mathrm{CaCO}_{3}$ system in the oceans. Science 305, 362-366 (2004).

2. Doney, S. C., Fabry, V. J., Feely, R. A. \& Kleypas, J. A. Ocean acidification: the other $\mathrm{CO}_{2}$ problem. Annu. Rev. Mar. Sci. 1, 169-192 (2009).

3. Kleypas, J. A. et al. Geochemical consequences of increased atmospheric carbon dioxide on coral reefs. Science 284, 118-120 (1999).

4. Silverman, J., Lazar, B., Cao, L., Caldeira, K. \& Erez, J. Coral reefs may start dissolving when atmospheric $\mathrm{CO}_{2}$ doubles. Geophys. Res. Lett. 36, L05606 (2009).

5. Kroeker, K. J. et al. Impacts of ocean acidification on marine organisms: quantifying sensitivities and interaction with warming. Glob. Change Biol. 19, 1884-1896 (2013).

6. Albright, R. et al. Reversal of ocean acidification enhances net coral reef calcification. Nature 531, 362-365 (2016).

7. Albright, R. et al. Carbon dioxide addition to coral reef waters suppresses net community calcification. Nature 555, 516 (2018).

8. Silverman, J., Lazar, B. \& Erez, J. Community metabolism of a coral reef exposed to naturally varying dissolved inorganic nutrient loads. Biogeochemistry 84, 67-82 (2007).

9. Gattuso, J. P., Frankignoulle, M. \& Smith, S. V. Measurement of community metabolism and significance in the coral reef $\mathrm{CO}_{2}$ source-sink debate. Proc. Natl Acad. Sci. USA 96, 13017-13022 (1999).

10. DeCarlo, T. M. et al. Community production modulates coral reef $\mathrm{pH}$ and the sensitivity of ecosystem calcification to ocean acidification. J. Geophys. Res.: Oceans 122, 745-761 (2017).

11. Silverman, J., Lazar, B. \& Erez, J. Effect of aragonite saturation, temperature, and nutrients on the community calcification rate of a coral reef. J. Geophys. Res.: Oceans 112, C05004 (2007).

12. Silverman, J. et al. Community calcification in Lizard Island, Great Barrier Reef: a 33 year perspective. Geochim. Cosmochim. Acta 144, 72-81 (2014).

13. Silverman, J. et al. Carbon turnover rates in the One Tree Island reef: a 40-year perspective. J. Geophys. Res.: Biogeosci. 117, G03023 (2012).

14. Cantin, N. E., Cohen, A. L., Karnauskas, K. B., Tarrant, A. M. \& McCorkle, D. C. Ocean warming slows coral growth in the central Red Sea. Science 329, 322-325 (2010).

15. Tanzil, J. T. et al. Regional decline in growth rates of massive Porites corals in Southeast Asia. Glob. Change Biol. 19, 3011-3023 (2013).

16. De'ath, G., Fabricius, K. \& Lough, J. Yes - Coral calcification rates have decreased in the last twenty-five years! Mar. Geol. 346, 400-402 (2013).

17. Helmle, K. P., Dodge, R. E., Swart, P. K., Gledhill, D. K. \& Eakin, C. M. Growth rates of Florida corals from 1937 to 1996 and their response to climate change. Nat. Commun. 2, 215 (2011).

18. Hughes, T. P. et al. Spatial and temporal patterns of mass bleaching of corals in the Anthropocene. Science 359, 80-83 (2018).

19. Chazottes, V., Le Campion-Alsumard, T., Peyrot-Clausade, M. \& Cuet, P. The effects of eutrophication-related alterations to coral reef communities on agents and rates of bioerosion (Reunion Island, Indian Ocean). Coral Reefs 21, 375-390 (2002).

20. Islam, M. N., Casareto, B. E. \& Suzuki, Y. Eutrophication accelerates carbonate dissolution under high $p \mathrm{CO}_{2}$ condition in coral reef ecosystem. J. Sci. Res. 8, 427-438 (2016).

21. Wilkinson, C. Status of Coral Reefs of the World: 2008 (Global Coral Reef Monitoring Network and Reef and Rainforest Research Centre, Townsville, Australia, 2008).

22. Silverman, J. et al. Monitoring the status of coral reefs using a simplified technique to measure community metabolism: a case study from the northern Gulf of Aqaba, Red Sea. In Proc. of the 10th International Coral Reef Symposium, Okinawa, Japan 1174-1181 (ReefBase, 2005).

23. Cyronak, T. et al. Taking the metabolic pulse of the world's coral reefs. PLoS ONE 13, e0190872 (2018).

24. Steiner, Z. et al. Basin-scale estimates of pelagic and coral reef calcification in the Red Sea and Western Indian Ocean. Proc. Natl Acad. Sci. USA 111, 16303-16308 (2014).

25. Fry, C. H., Tyrrell, T., Hain, M. P., Bates, N. R. \& Achterberg, E. P. Analysis of global surface ocean alkalinity to determine controlling processes. Mar. Chem. 174, 46-57 (2015).
26. Takahashi, T. et al. Climatological distributions of $\mathrm{pH}, \mathrm{pCO}_{2}$, total $\mathrm{CO}_{2}$, alkalinity, and $\mathrm{CaCO}_{3}$ saturation in the global surface ocean, and temporal changes at selected locations. Mar. Chem. 164, 95-125 (2014).

27. Liu, Q. et al. How significant is submarine groundwater discharge and its associated dissolved inorganic carbon in a river-dominated shelf system? Biogeosciences 9, 1777-1795 (2012).

28. Zolina, O., Dufour, A., Gulev, S. K. \& Stenchikov, G. Regional hydrological cycle over the Red Sea in ERA-Interim. J. Hydrometeorol. 18, 65-83 (2017).

29. Sofianos, S. S. \& Johns, W. E. An Oceanic General Circulation Model (OGCM) investigation of the Red Sea circulation, 1. Exchange between the Red Sea and the Indian Ocean. J. Geophys. Res.: Oceans 107, 11 (2002).

30. Sofianos, S. S. \& Johns, W. E. An Oceanic General Circulation Model (OGCM) investigation of the Red Sea circulation: 2. Three-dimensional circulation in the Red Sea. J. Geophys. Res.: Oceans 108, 15 (2003).

31. Cember, R. P. On the sources, formation, and circulation of Red Sea deep water. J. Geophys. Res.: Oceans 93, 8175-8191 (1988).

32. Krumgalz, B. S. \& Erez, J. Chemical Oceanography Survey of the Northern Red Sea, the Straits of Tiran and the Gulf of Elat (I.O.L.R., 1984).

33. Fine, M., Gildor, H. \& Genin, A. A coral reef refuge in the Red Sea. Glob. Change Biol. 19, 3640-3647 (2013).

34. Wurgaft, E., Steiner, Z., Luz, B. \& Lazar, B. Evidence for inorganic precipitation of $\mathrm{CaCO}_{3}$ on suspended solids in the open water of the Red-Sea. Mar. Chem. 186, 145-155 (2016).

35. Weiss, R. F., Broecker, W. S., Craig, H., \& Spencer, D. GEOSECS Indian Ocean Expedition, Hydrographic Data 1977- 1978 Vol. 5 (U.S. Government Printing Office, Washington DC, 1983).

36. Eshel, G., Cane, M. A. \& Blumenthal, M. B. Modes of subsurface, intermediate, and deep water renewal in the Red Sea. J. Geophys. Res.: Oceans 99, 15941-15952 (1994)

37. German, C. R. \& Seyfried, W. E. in Treatise on Geochemistry, Vol. 8 (eds Holland, H.D. \& Turekian, K.K.) Ch. 7 (Elsevier, Oxford, 2014).

38. Le Gal, V. et al. Heat flow, morphology, pore fluids and hydrothermal circulation in a typical Mid-Atlantic Ridge flank near Oceanographer Fracture Zone. Earth Planet. Sci. Lett. 482, 423-433 (2018).

39. Humphris, S. E. \& Thompson, G. Hydrothermal alteration of oceanic basalts by seawater. Geochim. Cosmochim. Acta 42, 107-125 (1978).

40. Danielsson, L. G., Dyrssen, D. \& Graneli, A. Chemical investigations of Atlantis II and Discovery brines in the Red Sea. Geochim. Cosmochim. Acta 44, 2051-2065 (1980).

41. Davis, A. C., Bickle, M. J. \& Teagle, D. A. H. Imbalance in the oceanic strontium budget. Earth Planet. Sci. Lett. 211, 173-187 (2003).

42. Milliman, J. D. Marine Carbonates (Springer-Verlag, Berlin, 1974).

43. Enmar, R. et al. Diagenesis in live corals from the Gulf of Aqaba. I. The effect on paleo-oceanography tracers. Geochim. Cosmochim. Acta 64, 3123-3132 (2000).

44. Gaetani, G. A. \& Cohen, A. L. Element partitioning during precipitation of aragonite from seawater: a framework for understanding paleoproxies. Geochim. Cosmochim. Acta 70, 4617-4634 (2006).

45. Müller, $\mathrm{M}$. N. et al. Influence of temperature and $\mathrm{CO}_{2}$ on the strontium and magnesium composition of coccolithophore calcite. Biogeosciences 11, 1065-1075 (2014)

46. Elderfield, H., Bertram, C. J. \& Erez, J. Biomineralization model for the incorporation of trace elements into foraminiferal calcium carbonate. Earth Planet. Sci. Lett. 142, 409-423 (1996).

47. Carpenter, S. J. \& Lohmann, K. C. Sr/Mg ratios of modern marine calcite: empirical indicators of ocean chemistry and precipitation rate. Geochim. Cosmochim. Acta 56, 1837-1849 (1992).

48. Broecker, W. S. \& Oversby, V. M. Chemical Equilibria in the Earth (McGrawHill, New York, 1971)

49. Siccha, M., Trommer, G., Schulz, H., Hemleben, C. \& Kucera, M. Factors controlling the distribution of planktonic foraminifera in the Red Sea and implications for the development of transfer functions. Mar. Micropaleontol. 72, 146-156 (2009).

50. Lozano-Cortés, D. et al. Coral bleaching in Saudi Arabia affecting both the Red Sea and Arabian Gulf. Reef Encount. 31, 50-52 (2016).

51. Pearman, J. K., Kürten, S., Sarma, Y. V. B., Jones, B. H. \& Carvalho, S. Biodiversity patterns of plankton assemblages at the extremes of the Red Sea. FEMS Microbiol. Ecol. 92, piw002 (2016).

52. Monnin, C. A thermodynamic model for the solubility of barite and celestite in electrolyte solutions and seawater to 200 degrees $\mathrm{C}$ and to $1 \mathrm{kbar}$. Chem. Geol. 153, 187-209 (1999).

53. Erez, J., Takahashi, K. \& Honjo, S. In-situ dissolution experiment of Radiolaria in the central North Pacific Ocean. Earth Planet. Sci. Lett. 59, 245-254 (1982).

54. Loya, Y. How to influence environmental decision makers? The case of Eilat (Red Sea) coral reefs. J. Exp. Mar. Biol. Ecol. 344, 35-53 (2007).

55. Lazar, B. et al. in Aqaba-Eilat, the Improbable Gulf. Environment, Biodiversity and Preservation (ed. Por, F. D.) 75-95 (Magnes Press, Jerusalem, 2008). 
56. Shaked, Y. \& Genin, A. Annual Report of the Israel National Monitoring Program in the Northern Gulf of Aqaba (Isreal Ministry of the Environment, 2017).

57. Shlesinger, T. \& Loya, Y. Recruitment, mortality, and resilience potential of scleractinian corals at Eilat, Red Sea. Coral Reefs 35, 1357-1368 (2016).

58. Steiner, Z. et al. The effect of bioturbation in pelagic sediments: lessons from radioactive tracers and planktonic foraminifera in the Gulf of Aqaba, Red Sea. Geochim. Cosmochim. Acta 194, 139-152 (2016).

59. Genin, A. \& Shaked, Y. Annual Report of the Israel National Monitoring Program in the Northern Gulf of Aqaba (Israel Ministry of the Environment, 2005).

60. Riegl, B. M., Bruckner, A.W., Rowlands, G. P., Purkis, S. J. \& Renaud, P. Red Sea coral reef trajectories over 2 decades suggest increasing community homogenization and decline in coral size. PLos ONE 7, e38396 (2012).

61. Orr, J. C. et al. Anthropogenic ocean acidification over the twenty-first century and its impact on calcifying organisms. Nature 437, 681-686 (2005).

62. Hughes, T. P. et al. Global warming and recurrent mass bleaching of corals. Nature 543, 373-377 (2017).

63. Chaidez, V., Dreano, D., Agusti, S., Duarte, C. M. \& Hoteit, I. Decadal trends in Red Sea maximum surface temperature. Sci. Rep. 7, 8144 (2017).

64. Genin, A., Lazar, B. \& Brenner, S. Vertical mixing and coral death in the Red Sea following the eruption of Mount Pinatubo. Nature 377, 507-510 (1995).

65. Islam, M. N., Casareto, B. E., Higuchi, T., Niraula, M. P. \& Suzuki, Y. Contribution of coral rubble associated microbial community to the dissolution of calcium carbonate under high $\mathrm{pCO}_{2}$. Galaxea, J. Coral Reef Stud. 14, 119-131 (2012).

66. Schönberg, C. H. L., Fang, J. K. H., Carreiro-Silva, M., Tribollet, A. \& Wisshak, M. Bioerosion: the other ocean acidification problem. ICES J. Mar. Sci. 74, 895-925 (2017).

67. de Nooijer, L. J., Toyofuku, T. \& Kitazato, H. Foraminifera promote calcification by elevating their intracellular pH. Proc. Natl Acad. Sci. USA 106, 15374-15378 (2009).

68. Krumgalz, B. S., Erez, J. \& Chen, C. T. A. Anthropogenic $\mathrm{CO}_{2}$ penetration in the northern Red Sea and in the Gulf of Elat (Aqaba). Oceanol. Acta 13, 283-290 (1990).

69. Glynn, P. W. \& Manzello, D. P. in Coral Reefs in the Anthropocene (ed. Birkeland, C.) Ch. 4 (Springer, Netherlands, Dordrecht, 2015).

70. Hallock, P. The role of nutrient availability in bioerosion: consequences to carbonate buildups. Palaeogeogr. Palaeoclimatol. Palaeoecol. 63, 275-291 (1988).

71. Burke, L. Reefs at Risk Revisited (World Resources Institute, Washington, DC, 2011).

72. Kürten, B. et al. Influence of environmental gradients on $\mathrm{C}$ and $\mathrm{N}$ stable isotope ratios in coral reef biota of the Red Sea, Saudi Arabia. J. Sea Res. 85, 379-394 (2014).

73. Eppley, R. W., Rogers, J. N. \& McCarthy, J. J. Half-saturation constants for uptake of nitrate and ammonium by marine phytoplankton. Limnol. Oceanogr. 14, 912-920 (1969).

74. Feng, Y. Y. et al. Effects of increased $\mathrm{pCO}_{2}$ and temperature on the North Atlantic spring bloom. I. The phytoplankton community and biogeochemical response. Mar. Ecol. Prog. Ser. 388, 13-25 (2009)
75. Sass, E. \& Ben-Yaakov, S. The carbonate system in hypersaline solutions: dead sea brines. Mar. Chem. 5, 183-199 (1977).

76. Millero, F. J. \& Poisson, A. International one-atmosphere equation of state of seawater. Deep-Sea Res. Part A-Oceanogr. Res. Pap. 28, 625-629 (1981)

77. Fofonoff, N. P. Physical properties of seawater: a new salinity scale and equation of state for seawater. J. Geophys. Res.: Oceans 90, 3332-3342 (1985)

78. Burton, J. D. in Oceanography: An Illustrated Guide (eds Summerhayes, C. P. \& Thorpe, S. A.) Ch. 11 (Manson, London, 1996).

79. Schlitzer, R. Ocean Data View (2018).

\section{Acknowledgements}

This study was supported by ERC Grant Stg (307582) CARBONSINK to A.V.T. and a Blavatnik postdoctoral fellowship to Z.S. We thank Mervyn Greaves for advice and support in ICP analyses.

\section{Author contributions}

J.S and Z.S. designed the study. E.H., J.S. and Z.S. performed research. Z.S., J.S. and A.V.T. analysed the data and wrote the paper.

\section{Additional information}

Supplementary Information accompanies this paper at https://doi.org/10.1038/s41467018-06030-6.

Competing interests: The authors declare no competing interests.

Reprints and permission information is available online at http://npg.nature.com/ reprintsandpermissions/

Publisher's note: Springer Nature remains neutral with regard to jurisdictional claims in published maps and institutional affiliations.

(c) (1) Open Access This article is licensed under a Creative Commons Attribution 4.0 International License, which permits use, sharing, adaptation, distribution and reproduction in any medium or format, as long as you give appropriate credit to the original author(s) and the source, provide a link to the Creative Commons license, and indicate if changes were made. The images or other third party material in this article are included in the article's Creative Commons license, unless indicated otherwise in a credit line to the material. If material is not included in the article's Creative Commons license and your intended use is not permitted by statutory regulation or exceeds the permitted use, you will need to obtain permission directly from the copyright holder. To view a copy of this license, visit http://creativecommons.org/ licenses/by/4.0/.

(C) The Author(s) 2018 